\title{
A Comparative Study between the Internal and External Internet Broadcasting on AL-NAJAf City
}

\author{
Abdulhussein Abdulmohson \\ University of Kufa \\ Faculty of Education \\ Computer Science Department
}

\author{
Nabeel Salih Ali \\ University of Kufa \\ IT-RDC Centre
}

\author{
Zaid Abdi Alkareem Alyasseri \\ University of Kufa \\ Faculty of Engineering \\ ECE Department
}

\begin{abstract}
Internet-based technology such as mobile and computers have been widely grown over the world in the recent years. Indoor Internet wireless has spread rapidly instead of a traditional method which using cable-based services to get the Internet services. Today hardly non-exist these devices in any house or office. A lot of people concerned about the effect these devices especially effect on children. Hundreds of reports talked about the Electromagnetic field (EMF) emitted by wireless devices and its effect on both human and animal. In Iraq the wireless broadcasting has been divided into two types, these kinds include indoor wireless broadcasting and outdoor wireless broadcasting by using towers. In this paper, comparing between two type of broadcasting from the perspective of power density which is accredited by most of the organization that specializes in EMF. In the indoor broadcasting, different types of wireless broadcasting devices take as a sample to measure the power density, whilst, the in outdoor broadcasting Previous measurements take to compare with indoor measurements. The measurements obtained from this study show that the effects of the internal broadcasting devices are more influential than the external broadcasting devices that connected to the towers, especially for very close distances. Therefore, this study emphasizes to remove these devices from the bedrooms and classrooms and patients rooms.
\end{abstract}

\section{Keywords}

EMF, Wireless device, Broadcasting, Power density.

\section{INTRODUCTION}

Wireless broadcasting refers to transferring information and data between two or more points that are not connected by any conductor [1]. There are many ways for wireless broadcasting [2]. the most important ways are a point to point broadcasting, Broadcast to a certain degree angle and broadcast in all directions. most of the wireless broadcasting devices use $2.4 \mathrm{GHz}$ frequencies and $5.6 \mathrm{GHz}$ frequencies [3] Whereas, most of the indoor devices used $2.4 \mathrm{GHz}$. recently, many of towers Spread in many of countries like IRAQ used for outdoor wireless broadcasting due to lack of fiber optic infrastructure[4]. These towers carry of wireless broadcast devices use $5.6 \mathrm{GHz}$. These types of broadcasting make people worried because of reports of the relation between of exposure from these devices with health [5]. In this study, focuses on the comparing the of the associated effect of external and internal wireless broadcasting To know who is more dangerous to health by measuring the power density associated with the broadcast and comparing it with the permitted levels. Most of the previous work focused on one side only either on indoor broadcasting (Wi-Fi) or outdoor broadcasting. Some of the indoor broadcasting used the animal for laboratory experiments. Rats used to check If there is an impact of lipid peroxidation when it exposed to 2.45 GHz EMF. The level of lipid peroxidation increased in the blood of Experimental rats when it Exposed to EMF. In this test, the researcher used thirty male rats divided into five groups exposed to EMF for 28 days[6]. Also, another researcher [7] used five groups of rats to test the impact of $2.45 \mathrm{GHz}$ exposure for two groups which exposed to it for 60 $\mathrm{min} /$ day for 30 days the lip peroxidation for this group, cell viability and cytosolic were higher than other groups which are not exposed to EMF. whilst, another test used two groups of rats, one exposed to $2.45 \mathrm{GHz}$ for 24 hours/day during 12 months, the other group put in the same environment except for WI-FI[8]. The exposed group have an increase of head effect, declined thickness of tunica albuginea and the weight of epididymis. , Three groups of Rats used in this study, intrauterine group, postnatal periods, sham-exposed group. the results show delayed puberty in female rats which exposed to $2.45 \mathrm{GHz}$, also increased of total oxidant status and oxidative stress index values in the brain which can explain as chronic stress induced by the exposure to $2.45 \mathrm{GHz}$ electric magnetic field [9]. These studies have been extended to examine the effect of using WI-FI by Laptop to sperm motility and sperm DNA fragmentation of men [10]. This study shows that the sperm DNA fragmentation has been increased while the decrease the of sperm motility. While other studies focus on the effect of exposure to WI-FI on brain tissue [11]. this study explains that the long exposure to WI-FI may lead to harmful effect such as Neurological diseases. In spite of most of studies focus on effect of indoor WI-FI broadcasting on health, but also new studies start to study the effect of outdoor broadcasting on health and compare the results with international standards reading [4], Where he measure the power density of wireless broadcasting and compare it with outdoor power density international standard to discuss whether this type of broadcasting exceed the Allowed levels of broadcast. In this paper, we measure power density of indoor broadcasting for many of WI-FI devices which use the indoor broadcasting of the Internet. the results compared with the results that measure for outdoor broadcasting device [12] to conclude which type of broadcasting much danger for a human.

\section{MEASUREMENT METHOD}

\subsection{Measurement device}

In this study, adopts SRM-3006 for power density measurement. SRM (Selective Radiation Meter) is Safety Test Solutions which developed to address safety concerns in electromagnetic fields. The SRM-3006 as shown in figure 1 . Used to measure power density for different indoor 
broadcasting devices, these devices are Cisco Aironet 1130G, Laptop Dell Inspiron N5010, TP-LINK AC1350, TP-Link N300 Router, Alcatel.lucent I-240w-A. The indoor measurements have been done at the different distance, start from $0.5 \mathrm{~m}$ to 4.5 meter, all indoor devices work on $2.4 \mathrm{GHZ}$.

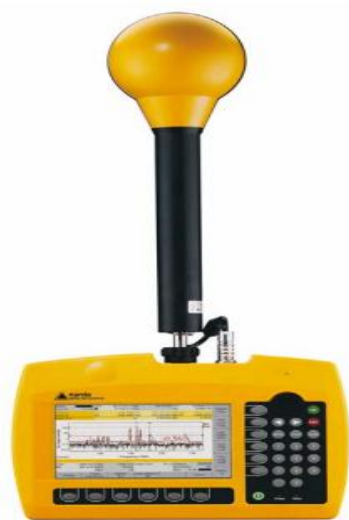

Fig 1: SRM-3006 Selective Radiation Meter

\subsection{Tested devices}

Table 1. Power density reading for multiple Indoor

\begin{tabular}{|c|c|c|}
\hline \multicolumn{3}{|c|}{ devices } \\
\hline $\begin{array}{c}\text { Type of indoor } \\
\text { broadcasting } \\
\text { device }\end{array}$ & Distance & $\begin{array}{l}\text { Power density } \\
\mathrm{nW} / \mathrm{cm} 2\end{array}$ \\
\hline \multirow{5}{*}{$\begin{array}{l}\text { Cisco Aironet } \\
1130 \mathrm{G}\end{array}$} & 0.5 & 1315.168 \\
\hline & 1.5 & 164.281 \\
\hline & 2.5 & 65.391 \\
\hline & 3.5 & 13.047 \\
\hline & 4.5 & 6.543 \\
\hline \multirow{5}{*}{$\begin{array}{c}\text { Laptop Dell } \\
\text { Inspiron n5010 }\end{array}$} & 0.5 & 160.977 \\
\hline & 1.5 & 80.647 \\
\hline & 2.5 & 64.04 \\
\hline & 3.5 & 40.4191 \\
\hline & 4.5 & 12.7816 \\
\hline \multirow{5}{*}{$\begin{array}{c}\text { TP-LINK } \\
\text { AC1350 } \\
\text { wireless dual } \\
\text { band ( with } 5 \\
\text { Antenna) }\end{array}$} & 0.5 & 5088.4627 \\
\hline & 1.5 & 2550.2725 \\
\hline & 2.5 & 404.191 \\
\hline & 3.5 & 40.4191 \\
\hline & 4.5 & 16.0911 \\
\hline \multirow{5}{*}{$\begin{array}{l}\text { TP-Link N300 } \\
\text { Router }\end{array}$} & 0.5 & 518.433 \\
\hline & 1.5 & 337.186 \\
\hline & 2.5 & 32.711 \\
\hline & 3.5 & 8.228 \\
\hline & 4.5 & 2.064 \\
\hline Alcatel.lucent I- & 0.5 & 1625.832 \\
\hline
\end{tabular}

\begin{tabular}{|c|c|c|}
\hline 240w-A & 1.5 & 309.486 \\
\cline { 2 - 3 } & 2.5 & 81567 \\
\cline { 2 - 3 } & 3.5 & 25.871 \\
\cline { 2 - 3 } & 4.5 & 12.925 \\
\hline
\end{tabular}

\subsection{Outdoor tested devices}

In paper [4] we can see the outdoor devices that used to measure power density Emitted from these devices.

\subsection{Results and discussion}

Five indoor broadcasting devices are chosen as samples to measure the exposure of wireless broadcasting. The power density of these devices can show as in table 1. For each device five distance take to measure power density $(0.5,1.5$, 2.5, 3.5,4.5) meter. While for the outdoor broadcasting device the result takes from another study [1], which take AL-Najaf city as a sample which contains 1250 towers, each tower contains many types of broadcast devices. The measurement of outdoor broadcasting has been done at the high point of broadcasting based on [10], the result can show as in table 2 . From these tables, we can see that the effect of indoor broadcasting is more dangerous than the outdoor broadcasting. Although these type of broadcasting is less than International standards which are adopted by most of the countries and related organizations[1]. Although people are rarely close to half a meter away from the WI-FI radiation zone, but that does not mean there is no such thing as many people put these devices in bedroom , So the indoor devices specially these devices that have high power transmission (like TP-LINK AC1350 wireless dual band (with 5 Antenna) ) are more dangerous outdoor devices. The outdoor door devices broadcasting sometime do not reach $10 \%$ of the level of indoor broadcasting level.

Table 2. power density reading for multiple places in one Iraqi city[4]

\begin{tabular}{|c|c|c|}
\hline $\begin{array}{c}\text { Type of } \\
\text { broadcast }\end{array}$ & $\begin{array}{c}\text { Power density } \\
(\mathrm{mw} / \mathrm{cm} 2)\end{array}$ & $\begin{array}{c}\text { Distance from } \\
\text { source }\end{array}$ \\
\hline $\begin{array}{c}\text { WI-FI indoor } \\
\text { broadcast }\end{array}$ & 5088.4627 & 0.5 \\
\hline $\begin{array}{c}\text { WI-FI outdoor } \\
\text { broadcast }\end{array}$ & 405.6 & 50 \\
\hline $\begin{array}{c}\text { CDMA, GSM } \\
\text { 900, and GSM } \\
1800\end{array}$ & 3180 & 50 \\
\hline
\end{tabular}

\section{COMPARISON OF WIRELESS TRANSMISSION TYPES}

The comparison was based on the exposure of people to the broadcast. from Table 3., we can see the Exposure magnitude based on people location from a broadcast source. In spite of most of the studies focus on exposure to mobile towers, but actually, the exposure to some indoor devices is more dangers than exposure to mobiles tower. most of the people move away from outdoor towers at least a distance not less than 50 meters. the power density of mobile towers up to 3180 (MW/cm2)[12], while some of Indoor device Located at a distance of up to $0.5 \mathrm{~m}$ to people especially at bedroom Which means that exposure to more than $5000 \mathrm{MW} / \mathrm{cm} 2$. 
Table 3. Comparison study of different broadcasting types

\begin{tabular}{|c|c|c|c|}
\hline $\begin{array}{l}\text { Place } \\
\text { (Latitude) }\end{array}$ & $\begin{array}{l}\text { Place } \\
\text { (Longitude) }\end{array}$ & $\begin{array}{l}\text { Time of } \\
\text { reading }\end{array}$ & $\begin{array}{l}\text { Power } \\
\text { density }\end{array}$ \\
\hline $\begin{array}{l}31^{\circ} 56^{\prime} 34.18 \\
\text { "N }\end{array}$ & $\begin{array}{l}44^{\circ} 25^{\prime} 42.72^{\prime \prime} \\
\mathrm{E}\end{array}$ & 09:01AM & $\begin{array}{l}\text { 405.6nw/ } \\
\mathrm{cm}^{2}\end{array}$ \\
\hline $\begin{array}{l}31^{\circ} 57^{\prime} 46.50 \\
\text { "N }\end{array}$ & $44^{\circ} 23^{\prime} 5.40^{\prime \prime} \mathrm{E}$ & 09:51AM & $\begin{array}{l}410.4 \mathrm{nw} / \\
\mathrm{cm}^{2}\end{array}$ \\
\hline $\begin{array}{l}31^{\circ} 57^{\prime} 26.38 \\
\text { "N }\end{array}$ & $44^{\circ} 24^{\prime} 6.55^{\prime \prime} \mathrm{E}$ & $10: 21 \mathrm{AM}$ & $\begin{array}{l}413.6 \mathrm{nw} / \\
\mathrm{cm}^{2}\end{array}$ \\
\hline $\begin{array}{l}31^{\circ} 58^{\prime} 03.76 \\
\text { "N }\end{array}$ & $\begin{array}{l}44^{\circ} 22^{\prime} 54.62^{\prime \prime} \\
\mathrm{E}\end{array}$ & 10:59AM & $\begin{array}{l}423.8 \mathrm{nw} / \\
\mathrm{cm}^{2}\end{array}$ \\
\hline $\begin{array}{l}31^{\circ} 58^{\prime} 24.73 \\
\text { "N }\end{array}$ & $44^{\circ} 26^{\prime} 8.81^{\prime \prime} \mathrm{E}$ & 11:24AM & $\begin{array}{l}433.2 \mathrm{nw} / \\
\mathrm{cm}^{2}\end{array}$ \\
\hline $\begin{array}{l}31^{\circ} 58^{\prime} 34.61 \\
" \mathrm{~N}\end{array}$ & $\begin{array}{l}44^{\circ} 19^{\prime} 56.68^{\prime \prime} \\
\mathrm{E}\end{array}$ & 11:51PM & $\begin{array}{l}439.9 \mathrm{nw} / \\
\mathrm{cm}^{2}\end{array}$ \\
\hline $\begin{array}{l}31^{\circ} 59^{\prime} 09.59 \\
" \mathrm{~N}\end{array}$ & $\begin{array}{l}44^{\circ} 19^{\prime} 20.91 " \\
\mathrm{E}\end{array}$ & 12:33PM & $\begin{array}{l}440.2 \mathrm{nw} / \\
\mathrm{cm}^{2}\end{array}$ \\
\hline $\begin{array}{l}31^{\circ} 59^{\prime} 56.41 \\
" \mathrm{~N}\end{array}$ & $44^{\circ} 25^{\prime} 8.61^{\prime \prime} \mathrm{E}$ & 01:09PM & $\begin{array}{l}429.1 \mathrm{nw} / \\
\mathrm{cm}^{2}\end{array}$ \\
\hline $\begin{array}{l}31^{\circ} 59 ' 29.69 \\
" \mathrm{~N}\end{array}$ & $\begin{array}{l}44^{\circ} 19^{\prime} 46.30^{\prime \prime} \\
\mathrm{E}\end{array}$ & 01:42PM & $\begin{array}{l}418.7 \mathrm{nw} / \\
\mathrm{cm}^{2}\end{array}$ \\
\hline $\begin{array}{l}31^{\circ} 59^{\prime} 31.68 \\
\text { "N }\end{array}$ & $\begin{array}{l}44^{\circ} 21^{\prime} 32.31^{\prime \prime} \\
\mathrm{E}\end{array}$ & 02:03PM & $\begin{array}{l}428.4 \mathrm{nw} / \\
\mathrm{cm}^{2}\end{array}$ \\
\hline
\end{tabular}

\section{CONCLUSION}

The widespread of the use of the equipment for wireless internet broadcasting, whether for internal or external wireless broadcasting and the lack of control of these devices and places of their presence to the extent of their presence in the bedrooms and children's rooms, schools and hospitals. Without taking into account the impact of these devices on humans. The main purpose of this paper is to examine the impact of the internal broadcast devices and compare it with external radio transmission to indicate what is more dangerous to humans. This paper has helped to obtain measurements of power density levels for the internal broadcasting of the internet for different types of devices and compares with other reading for the external broadcasting of the internet. It has shown that the power density levels do not exceed the international standard for emf exposure, although the power density of the broadcast has more than 10 times the external wireless transmission, especially when approaching a distance of less than half a meter from some types of devices. The use of these devices without meeting international standards or placing them in the children's room may represent a future danger to them, especially that EMF exposure may continue for long hours a day.

\section{FUTURE WORK}

In the future direction, intend to extend this study to includes different environments and measurements aspects such as the levels of the broadcast power density as well external wireless transmission and radio transmission.

\section{REFERENCES}

[1] Tse, David, and Pramod Viswanath. Fundamentals of wireless communication. Cambridge university press, 2005.

[2] Wireless. (2017, May 20). In Wikipedia, The Free Encyclopedia. Retrieved 15:08, June 17, 2017 , from https://en.wikipedia.org/w/index.php?title=Wireless\&old id $=781340885$

[3] Wi-Fi. (2017, June 17). In Wikipedia, The Free Encyclopedia. Retrieved 08:35, June 18, 2017 , from https://en.wikipedia.org/w/index.php?title=WiFi\&oldid $=786164417$

[4] Abdulmohson, A. (2017). Impact Of Random Broadcast Of The Internet On Human Health: A Field Study On AlNajaf City. Journal Of Theoretical \& Applied Information Technology, 95(8).

[5] Ahlbom, Anders, et al. "Epidemiology of health effects of radiofrequency exposure." Environmental health perspectives 112.17 (2004): 1741

[6] Gumral, Nurhan, et al. "Effects of selenium and Lcarnitine on oxidative stress in blood of rat induced by $2.45-\mathrm{GHz}$ radiation from wireless devices." Biological trace element research 132.1 (2009): 153-163.

[7] . Nazıroğlu, M., et al. "Melatonin modulates wireless (2.45 GHz)-induced oxidative injury through TRPM2 and voltage gated $\mathrm{Ca} 2+$ channels in brain and dorsal root ganglion in rat." Physiology \& behavior 105.3 (2012): 683-692.

[8] Dasdag, Suleyman, et al. "Effect of long-term exposure of $2.4 \mathrm{GHz}$ radiofrequency radiation emitted from Wi-Fi equipment on testes functions." Electromagnetic biology and medicine 34.1 (2015): 37-42.

[9] Sangun, Ozlem, et al. "The effects of long-term exposure to a $2450 \mathrm{MHz}$ electromagnetic field on growth and pubertal development in female Wistar rats." Electromagnetic biology and medicine 34.1 (2015): 63-71.

[10] Avendaño, C., et al. "Laptop expositions affect motility and induce DNA fragmentation in human spermatozoa in vitro by a non-thermal effect: a preliminary report." Fertility and Sterility 94.4 (2010): S73.

[11] Dasdag, Suleyman, et al. "Effects of $2.4 \mathrm{GHz}$ radiofrequency radiation emitted from Wi-Fi equipment on microRNA expression in brain tissue." International journal of radiation biology 91.7 (2015): 555-561.

[12] Kumar, Girish. "Cell phone/Tower Radiation Hazards and Solutions." Electrical Engineering Department, IITBombay Newslettet 1.2 (2013): 1-8. 